\title{
The presence of pathogens and heavy metals in urban peregrine falcons (Falco peregrinus)
}

\author{
Ewelina Pyzik ${ }^{1}$ (D), Marta Dec $^{1}$, Dagmara Stępień-Pyśniak ${ }^{1}$ (D), Agnieszka Marek ${ }^{1}$ (D), Jose Louis Valverde Piedra² (D), \\ Agnieszka Chałabis-Mazurek2 ${ }^{2}$, Klaudiusz Szczepaniak ${ }^{3}$ (D) and Renata Urban-Chmiel ${ }^{1}$ (i)
}

1. Department of Veterinary Prevention and Avian Diseases, Faculty of Veterinary Medicine, University of Life Sciences, Akademicka 12, 20-033 Lublin, Poland; 2. Department of Preclinical Veterinary Sciences, Faculty of Veterinary Medicine, University of Life Sciences in Lublin, Lublin, Poland; 3. Department of Veterinary Parasitology and Fish Diseases, Faculty of Veterinary Medicine, University of Life Sciences, Akademicka 12, 20-033 Lublin, Poland.

Corresponding author: Renata Urban-Chmiel, e-mail: renata.urban@up.lublin.pl

Co-authors: EP: ewelina.pyzik@up.lublin.pl, MD: marta.dec@up.lublin.pl, DS: dagmara.stepien@up.lublin.pl, AM: agnieszka.marek@up.lublin.pl, JLVP: jose.valverde@up.lublin.pl, AC: agnieszka.mazurek@up.lublin.pl, KS: klaudiusz.szczepaniak@up.lublin.pl

Received: 18-01-2021, Accepted: 17-05-2021, Published online: 03-07-2021

doi: www.doi.org/10.14202/vetworld.2021.1741-1751 How to cite this article: Pyzik $E$, Dec M, Stępień-Pyśniak D, Marek A, Piedra JLV, Chałabis-Mazurek A, Szczepaniak K, Urban-Chmiel R (2021) The presence of pathogens and heavy metals in urban peregrine falcons (Falco peregrinus), Veterinary World, 14(7): 1741-1751.

\begin{abstract}
Background and Aim: Wild birds raised in urban environments may be exposed to many negative factors, including biological and chemical toxic elements. The aim of the study was to assess the occurrence of bacteria and parasites in wild birds, based on the example of the peregrine falcon (Falco peregrinus) as a potential indicator of bacterial drug resistance genes. Toxicological contamination was also analyzed to determine the impact of urbanized areas on this predatory species, in terms of its health, welfare, and survival in urban environments.
\end{abstract}

Materials and Methods: The samples consisted of down feathers and fresh feces obtained from seven falcon chicks (during obligatory veterinary examination) reared in two nests located in the Lublin region (Lublin and Puławy). Bacteria and parasites were isolated directly from feces by classical microbiological methods, polymerase chain reaction, and matrixassisted laser desorption/ionization time-of-flight mass spectrometry (MS). The down feathers and feces of birds were used for toxicological testing by plasma inductively coupled plasma MS to assess the concentrations of selected heavy metals (cadmium [Cd], lead [Pb], arsenic [As], zinc [Zn], and copper [Cu]).

Results: The study revealed the presence of a diverse microbiome in the falcon chicks, among which Escherichia coli, Enterococcus spp., and Staphylococcus spp. bacteria and parasites of the genus Caryospora were dominant. The presence of drug resistance genes was also confirmed among the pathogens. The toxicological analysis found high concentrations of toxic heavy metals, including $\mathrm{Cd}, \mathrm{Pb}, \mathrm{As}$, and $\mathrm{Zn}$, in the downy feathers and feces of peregrine chicks.

Conclusion: Predatory free-living birds living in urban environments not only can be infected with various pathogens but may also show contamination with heavy metals, which could influence their natural resistance, condition, and welfare.

Keywords: bacteria, falcons, health status, toxic elements, welfare.

\section{Introduction}

Wild birds, due to their wide geographical range and close contact with humans, may be a potential reservoir of microorganisms with antibiotic resistance genes [1]. Their presence within human settlements and contact with chemical agents, antibiotics, sulfonamides, and other toxic substances may have a significant impact on the composition of their microbiota as well as their exposure to heavy metals or other toxins. Wild migratory birds in temperate climates have been shown to have the most diverse bacterial microbiota, in which the most commonly isolated bacteria include strains of Escherichia coli,

Copyright: Pyzik, et al. Open Access. This article is distributed under the terms of the Creative Commons Attribution 4.0 International License (http://creativecommons.org/licenses/by/4.0/), which permits unrestricted use, distribution, and reproduction in any medium, provided you give appropriate credit to the original author(s) and the source, provide a link to the Creative Commons license, and indicate if changes were made. The Creative Commons Public Domain Dedication waiver (http://creativecommons.org/ publicdomain/zero/1.0/) applies to the data made available in this article, unless otherwise stated.
Salmonella, Campylobacter, Pasteurella multocida, and Borrelia burgdorferi $[1,2]$. It has been postulated that wild birds are reservoirs and potential carriers of antibiotic resistance genes. Numerous studies have confirmed the role of free-living birds in the prevalence of multidrug-resistant bacteria, which could be a significant pathway in transmission to other animals and humans $[3,4]$. Monitoring of the spatial and temporal distribution of resistant bacteria in wild birds can be an important diagnostic indicator in the control of drug-resistance vectors and thus help to reduce the growing global problem of antibiotic resistance.

The peregrine falcon (Falco peregrinus) is one of the most widespread raptors in the world and is found on all continents, including Antarctica. In Europe, it currently inhabits primarily the western and southern parts of the continent, including Great Britain, France, and Spain, as well as northern Scandinavia and Russia [5,6]. Due to food conditions, fairly close contact with livestock or companion animals, and indirect contact with humans, the peregrine falcon may 
be exposed to human pathogenic microorganisms, including Campylobacter spp., Salmonella, E. coli or Mycoplasma [7-9]. Due to close contact with rapidly developing urban environments, peregrine falcons can also be exposed to toxic elements such as cadmium $(\mathrm{Cd})$, copper $(\mathrm{Cu})$, and lead $(\mathrm{Pb})$, which can affect their health status, welfare, and immunity, with increased susceptibility to infection. Concentrations of toxic heavy metals in the organs of free-living birds may $\mathrm{Pb}$ to their death in regions contaminated with these elements $[10,11]$. Heavy metals enter the environment and undergo biomagnification in high trophic level organisms, in which they can reach toxic concentrations [12]. As environmental pollution increases, so does exposure of wildlife to xenobiotics (chemical substances not naturally produced by organisms), including highly toxic metals. One of the important chemical environmental pollutants, toxic even in low concentrations, is $\mathrm{Cd}$, which due to its ease of absorption and capacity for bioaccumulation in living organisms and biomagnification in the food chain poses a major threat to animals and humans health [10]. The mechanism of $\mathrm{Cd}$ toxicity is induction of oxidative stress and lipid peroxidation of cell membranes, which $\mathrm{Pbs}$ to changes in the metabolism and structure of cells and irreversible damage to them [11]. In the case of mercury $(\mathrm{Hg})$, which has the highest accumulation factor, toxicity poses a significant risk not only to humans and animals but also to ecosystems as well [12]. $\mathrm{Pb}$ is another widespread element in nature that does not undergo biodegradation or decomposition in the natural environment and accumulates in tissues [13].

The aim of the study was to assess the occurrence of potential pathogens and antibiotic resistance genes in bacteria isolated from peregrine falcons $(F$. peregrinus) that nest in the vicinity of humans. Given the potential hazards arising from increasing pollution of the environment, the concentrations of heavy metals known to be present in urban environments were determined in the feathers and feces of the birds.

\section{Materials and Methods}

\section{Ethical approval}

Ethical approval is not necessary for such type of study; however, samples were collected as per standard sample collection procedure without any harm to the birds.

\section{Study period and location}

The study was conducted in March 2019. The samples were collected from Lublin and Puławy of Poland. The samples were processed at Department of Veterinary Prevention and Avian Diseases, Faculty of Veterinary Medicine, University of Life Sciences in Lublin.

\section{Sample collections}

The study material consisted of fresh feces and down feathers collected from seven young falcons from two nests located in urban areas of the Lublin region

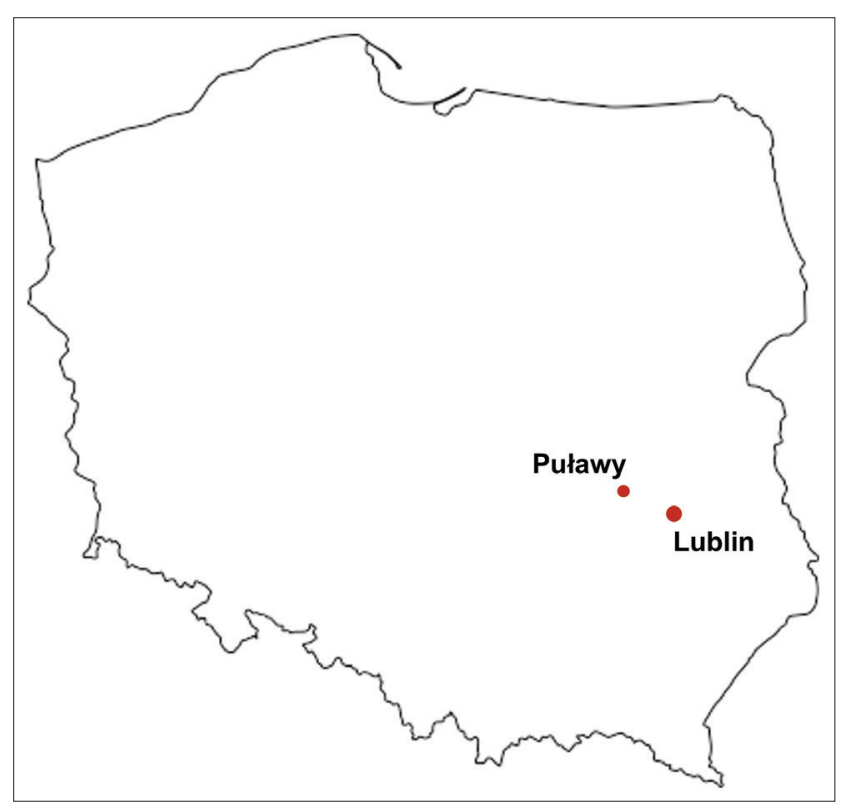

Figure-1: The map with the location of the peregrine falcons' nests.

(Lublin and Puławy) (Figure-1). The material was collected from 3-week-old chicks during obligatory veterinary examination and ringing. The average weight of the chicks from the nest in Lublin was $831 \mathrm{~g}$ (male $-645 \mathrm{~g}$ and female $1-955 \mathrm{~g}$; female $2-893 \mathrm{~g}$ ), while the average weight of the chicks from Puławy was $833 \mathrm{~g}$ (male $-700 \mathrm{~g}$; females 1 and $2-900 \mathrm{~g}$; female $3-899 \mathrm{~g}$ ). The material was delivered to the laboratory within $2 \mathrm{~h}$ in conditions compatible with transport standards (in sealed bags in a sample refrigerator). Parasitological diagnostics (phenotypic analysis) and bacteriological analysis (phenotypic analysis, polymerase chain reaction [PCR], and matrix-assisted laser desorption/ionization timeof-flight mass spectrometry (MALDI TOF MS) of the feces were carried out, as well as toxicological analysis by inductively coupled plasma MS (ICP-MS).

\section{Isolation and identification of bacteria}

The bacteria were identified by MALDI-TOF MS using a standard extraction method [14,15], with an UltrafleXtreme MALDI TOF mass spectrometer (Bruker, Germany). The mass spectra obtained from each isolate were processed with MALDI Biotyper 3.0 software (Bruker, Germany), and the results were shown as the top ten identification matches together with confidence scores (similarity of species) ranging from 0.000 to 3.000 , calculated by comparing the reference main spectra. According to the manufacturer's criteria, a log score $<1.700$ does not allow for reliable identification; a $\log$ score between 1.700 and 1.999 allows identification to the genus level; a log score between 2.000 and 2.299 means highly probable identification at the genus level and probable identification at the species level; and a $\log$ score $>2.300$ (2.300-3.000) indicates highly probable identification at the species level.

The E. coli strains were isolated on MacConkey agar, and pure cultures were stored on brain heart 
infusion (BHI) broth with $\sim 20 \%$ glycerol. To determine the phylogenetic groups of the isolates, five sets of primers for the genes $y j a, T s p E 4 . C 2, c h u A, s v g$, and uidA were used in multiplex PCR [16]. Amplicons were separated by electrophoresis in 3\% (wt/vol) high resolution agarose (Blirt, Poland). The phylogenetic groups (A, B1, B2, and D) were determined based on the PCR gel pattern.

Antibiotic susceptibility was determined by agar disk diffusion according to the guidelines of the Clinical and Laboratory Standards Institute [17] on Mueller-Hinton agar plates (Oxoid, UK), followed by application of antibiotic discs: Ampicillin (AM, $10 \mu \mathrm{g}$ ), cefotaxime (CTX, $30 \mu \mathrm{g}$ ), imipenem (IPM, $10 \mu \mathrm{g})$, gentamicin $(\mathrm{CN}, 10 \mu \mathrm{g})$, kanamycin $(\mathrm{K}, 30 \mu \mathrm{g})$, amikacin $(\mathrm{AK}, 30 \mu \mathrm{g})$ chloramphenicol $(\mathrm{C}, 30 \mu \mathrm{g})$, tetracycline (TE, $30 \mu \mathrm{g}$ ), trimethoprim (W, $5 \mu \mathrm{g}$ ), and ciprofloxacin (CIP, $5 \mu \mathrm{g}$ ). Inhibition zone diameters were measured after incubation at $35^{\circ} \mathrm{C}$ for $16-20 \mathrm{~h}$, and the results were interpreted according to the breakpoint recommended by the CLSI [17]. Antibiotic resistance genes, including tet genes $($ tet $(\mathrm{A}), \operatorname{tet}(\mathrm{B})$, and $\operatorname{tet}(\mathrm{C}))$, were detected in isolates with phenotypic tetracycline resistance by multiplex PCR [18]. PCR reactions were used to detect the presence of 24 genes associated with virulence in $E$. coli strains. The antibiotic resistance genes were determined on the basis of phenotypic tetracycline resistance (Table-1) [19-22]. PCR products were separated by electrophoresis (100 V) on $2 \%$ agarose gels, visualized by staining with SimplySafe (Eurx, Poland), and documented with the GelDoc system, using Quantity One software (BioRad, Germany).

Directly after collection, the bacteria were streaked onto Bile Esculin Azide Lab-Agar (Biocorp, Poland), a selective-differential medium for Enterococcus, supplemented with 5\% horse blood (ProAnimali, Poland), and incubated for $24-48 \mathrm{~h}$ at $37^{\circ} \mathrm{C}$. Colonies with typical enterococcal morphology were selected to identify specific Enterococcus species, and following incubation in BHI broth (Oxoid, UK), the isolates were stored at $80^{\circ} \mathrm{C}$ for further analysis. The enterococcal isolates were identified using MALDI-TOF MS [23]. The identification was confirmed by sequencing of the rpoA gene [24].

The susceptibility of the Enterococcus isolates was tested for 17 antibiotics: AM, cefotaxime (CTX, $30 \mu \mathrm{g})$, IPM, CN, AK, chloramphenicol (C, $30 \mu \mathrm{g})$, TE, sulfamethoxazole/trimethoprim (SXT, $25 \mu \mathrm{g}$ ), vancomycin (VA, $30 \mu \mathrm{g})$, penicillin $(\mathrm{P}, 10 \mu \mathrm{g})$, streptomycin $(\mathrm{S}, 25 \mu \mathrm{g})$, erythromycin $(\mathrm{E}, 15 \mu \mathrm{g})$, lincomycin (LS, $109 \mu \mathrm{g}$ ), tigecycline (TGC, $15 \mu \mathrm{g}$ ), teicoplanin (TEC, $30 \mu \mathrm{g}$ ), and linezolid (LZD, $30 \mu \mathrm{g}$ ). Inhibition diameter zones were measured after incubation at $35^{\circ} \mathrm{C}$ for 16-20 $\mathrm{h}$, and the results were interpreted according to CLSI [17]. Enterococcus faecalis ATCC 29212 was used as quality control.

Genomic DNA was extracted using the commercial GeneMATRIX Bacterial and Yeast Genomic
Table-1: Virulence genes determined in Escherichia coli isolates based on literature data.

\begin{tabular}{|c|c|c|}
\hline $\begin{array}{l}\text { PCR } \\
\text { method }\end{array}$ & Detected genes & References \\
\hline Multiplex 1 & $\begin{array}{l}\text { stx1, stx2, hylA, eaeA, } \\
\text { saa }\end{array}$ & Paton and Paton [20] \\
\hline Multiplex 2 & $\begin{array}{l}\text { ecs } V, \text { ent, bfpB, invE, } \\
\text { ast } A \text {, aggR, pic, ipaH, } \\
\text { elt, estIa, estIb }\end{array}$ & Turchi et al. [19] \\
\hline Multiplex 3 & ompT, iut $A$ & $\begin{array}{l}\text { van der Westhuizen } \\
\text { and Bragg [21] }\end{array}$ \\
\hline Multiplex 4 & tsh, pap-C, iss, irp-2 & Ewers et al. [22] \\
\hline Uniplex 1 & $c v a / c v i$ & Ewers et al. [22] \\
\hline Uniplex 2 & $i u c D$ & Ewers et al. [22] \\
\hline
\end{tabular}

$\mathrm{PCR}=$ Polymerase chain reaction

DNA Purification Kit (Eurx, Gdansk, Poland). Antibiotic-resistant isolates were tested by PCR for detection of the following resistance genes: vanA, vanB, vanC1, vanC2/C3, vanD, vanE, and van $G$ (glycopeptide-resistant isolates), blaZ and pbp5 (penicillin- and ampicillin-resistant), aph(30)-IIIa (kanamycin-resistant), ant(6)-Ia (streptomycin-resistant), $\operatorname{tet}(\mathrm{M}), \operatorname{tet}(\mathrm{L}), \operatorname{tet}(\mathrm{K})$, and $\operatorname{tet}(\mathrm{O})($ tetracycline-resis$\operatorname{tant})$, and $\operatorname{erm}(\mathrm{A}), \operatorname{erm}(\mathrm{B}), \operatorname{msr}(\mathrm{A} / \mathrm{B})$, and $m s r(\mathrm{C})$ (macrolide-resistant) [25].

The bacterial strains were isolated on mannitol agar (Chapman medium) and Columbia agar with 5\% sheep blood at $37^{\circ} \mathrm{C}$ for $24 \mathrm{~h}$. The resulting cultures were incubated in TSB broth (BTL and PL) at $37^{\circ} \mathrm{C}$ for $24 \mathrm{~h}$ to obtain optimal growth of pure strains in a liquid medium. Phenotypic identification of the bacterial isolates was carried out by Gram staining. Genetic identification was carried out by PCR and MALDITOF MS [26]. The drug-susceptibility of bacteria was determined by the agar disk diffusion method CLSI [17], followed by application of antibiotic discs (Oxoid, UK): Amoxicillin (AMC $30 \mu \mathrm{g}$ ), amoxicillin+clavulanic acid (AMC $30 \mu \mathrm{g}$ ) cefoxitin (FOX $30 \mu \mathrm{g}$ ), clindamycin (DA $2 \mu \mathrm{g}$ ), enrofloxacin (ENR $5 \mu \mathrm{g}), \mathrm{E}, \mathrm{CN}, \mathrm{LZD}$, neomycin (N $30 \mu \mathrm{g})$, VA, CIP, C, STX, P, polymyxin $(0.5-256 \mu \mathrm{g} / \mathrm{mL})$, TEC, TE, and tobramycin (TOB $10 \mu \mathrm{g}$ ). Staphylococcus aureus ATCC 25923 and S. aureus ATCC 29213 were used for quality control.

Identification of selected antibiotic resistance genes, tet $(\mathrm{K})$, blaZ, walKR, vraSR, and rpoB, was carried out for multidrug-resistant Staphylococcus spp. by multi-PCR $[27,28]$. The strains were tested for genes encoding staphylococcal enterotoxins A to E (sea, seb, sec, sed, and see) in multiplex PCR (Table-2). The conditions for PCR were described by Pyzik et al. [29].

\section{Isolation and identification of parazites}

Fresh fecal samples were obtained from the nests and from young falcons. The feces were mixed, placed in a Petri dish containing $2.5 \%(\mathrm{w} / \mathrm{v})$ aqueous potassium dichromate $\left(\mathrm{K}_{2} \mathrm{Cr}_{2} \mathrm{O}_{7}\right)$, and monitored daily. Oocysts were recovered by the flotation method with saturated saline solution (specific gravity $=1.20$ ) and 
Table-2: PCR conditions and primers used to detect toxicity genes in strains.

\begin{tabular}{|c|c|c|c|c|}
\hline Primer & Oligonucleotide sequence $\left(5^{\prime}-3^{\prime}\right) *$ & Gene & $\begin{array}{l}\text { Size of amplified } \\
\text { product (bp) }\end{array}$ & PCR conditions \\
\hline ESA1 & ACGATCAATTITTACAGC & sea & 144 & Initial denaturation $\left(5 \mathrm{~min}, 94^{\circ} \mathrm{C}\right)$; \\
\hline ESA2 & TGCATGTITCAGAGTTAATC & & & 30 cycles of amplification \\
\hline ESB1 & GAATGATATTAATTCGCATC & seb & 416 & - denaturation $1 \mathrm{~min} s e c, 94^{\circ} \mathrm{C}$, annealing \\
\hline ESB2 & TCTITGTCGTAAGATAAACTTC & & & $\left(1 \mathrm{~min}, 50^{\circ} \mathrm{C}\right)$, chain extension $(1 \mathrm{~min}$, \\
\hline ESC1 & GACATAAAAGCTAGGAATTT & $\mathrm{sec}$ & 257 & $\left.72^{\circ} \mathrm{C}\right)$ \\
\hline ESC2 & AAATCGGATTAACATTATCCA & & & Final chain extension $\left(2 \min , 55^{\circ} \mathrm{C}\right)$ \\
\hline ESD1 & TTACTAGTTTGGTAATATCTCCTT & sed & 334 & Final chain extension $\left(5 \min , 72^{\circ} \mathrm{C}\right)$; \\
\hline ESD2 & CCACCATAACAATTAATGC & & & $4^{\circ} \mathrm{C}$ cooling \\
\hline ESE1 & ATAGATAAAGTTAAAACAAGCAA & see & 170 & \\
\hline ESE2 & TAACTTACCGTGGACCC & & & \\
\hline
\end{tabular}

*The primer concentration was $0.04 \mu \mathrm{moL}$. PCR=Polymerase chain reaction

examined microscopically. In addition, $2 \mathrm{~g}$ of fecal samples were used to determine the number of oocysts per $\mathrm{g}$ of feces (OPG ratio) by the McMaster method. The taxonomic classification of coccidian protozoa was based on morphological details of fully sporulated oocysts [30]. Measurements were made on 20 oocysts by differential interference contrast microscopy using Nikon NIS-Elements software.

\section{Detection of heavy metals}

All heavy metals $(\mathrm{Pb}, \mathrm{Cd}$, arsenic [As], zinc $[\mathrm{Zn}]$, and $\mathrm{Cu})$ in the feces and down feathers were analyzed by ICP-MS according to Lodenius and Solonen [31]. Determination of metals was preceded by ashing of all samples (dry heat incineration). For this purpose, $0.054-0.078 \mathrm{~g}$ of feathers from each individual, according to availability, and 2.427-2.924 $\mathrm{g}$ of feces were mineralized in an electric furnace at a final temperature of $450^{\circ} \mathrm{C}$ (dry heat incineration). The resulting ash was dissolved in $1 \mathrm{M}$ nitric acid, filtered (Whatman No. 42, Sigma Aldrich, USA), and made up to the $10 \mathrm{~mL}$ mark. To determine the validity of the method, the certified reference material DOLT-3 (dogfish liver, National Research Council of Canada, 11 Ottawa, Canada) was subjected to the same analytical procedure.

Heavy metals were determined with a Varian 820-MS ICP mass spectrometer, using the following parameters: Plasma flow $16 \mathrm{dm}^{3} / \mathrm{min}$, auxiliary flow $1.10 \mathrm{dm}^{3} / \mathrm{min}$, nebulizer flow $0.88 \mathrm{dm}^{3} / \mathrm{min}$, sampling depth $6.5 \mathrm{~mm}$, RF power $1400 \mathrm{~W}$, pump rate $6 \mathrm{rpm}$, and stabilization delay $40 \mathrm{~s}$. Recoveries in the range of $90-110 \%$ were accepted as validation of the analytical procedure for the elements. The limits of detection obtained were $0.5,0.25,2.5,0.25$, and $4.0 \mu \mathrm{g} / \mathrm{L}^{-1}$ for $\mathrm{Cd}, \mathrm{Pb}, \mathrm{As}, \mathrm{Cu}$, and $\mathrm{Zn}$, respectively.

\section{Statistical analysis}

Statistical analysis of the concentrations of toxic elements was carried out by ANOVA in Statistica 10.0 software (Statistica, Poland). Because in a few cases, the concentrations of the metals were under the detection limit (Cd and As), Spearman rank correlation was calculated and tested. $\mathrm{p} \leq 0.05$ was considered significant. The results were presented as means and standard deviations.

\section{Results}

\section{Bacteria isolation and identification}

Presumptive E. coli isolates $(\mathrm{n}=4)$ grown on MacConkey agar were obtained from three birds (one male and two female) from the nest in Lublin. No E. coli strains were isolated from the birds from Puławy. Four isolates (S1, S2a, Sa, and Sb) were correctly identified by MALDI-TOF-MS as E. coli. Log score values for all samples were $>2$, which indicates correct identification to species level (Table-3).

Based on the electrophoretic profiles of multiplex PCR amplicons (yja, TspE4.C2, chuA, svg, and uidA), two $E$. coli isolates (Sa and S2a) were assigned to phylogenetic Group A and two isolates (S1 and $\mathrm{S} 2 \mathrm{~b})$ to Group B2. Detailed PCR results are presented in Figure-2.

All four isolates were susceptible to the antibiotics tested, except for strain S2a, which showed intermediate susceptibility to tetracycline and isolate $\mathrm{Sb}$, which was resistant to this antibiotic. The tet(A) gene was detected in both isolates (Table-3).

Of the 24 virulence genes considered in the study, only ast $A$ (encoding heat-stable enterotoxin 1 - EAST1), irp-2 (encoding iron-repressible high-molecular-weight proteins), iss (encoding increased serum survival protein), and pic (encoding a serine protease precursor) were detected in three of the four E. coli isolates.

On the basis of morphological analysis, five Enterococcus spp. strains were isolated from all tested samples. Detailed MALDI TOF MS analysis revealed that the strains belonged to the species Enterococcus hirae (two strains) and E. faecalis (three strains). Both bacterial species were isolated from the samples obtained from falcons nesting in Lublin, whereas only E. faecalis strains were isolated from falcons nesting in Puławy. Log score values obtained in MALDI TOF for Enterococcus strains were $>2.74$ in the case of four strains and $>1.7$ for one strain, which indicates correct identification to species level (Table-4).

The antibiotic resistance analysis confirmed resistance to lincomycin in all strains tested. All strains showed intermediate susceptibility to erythromycin. 
Table-3: Characterization of Escherichia coli strains isolated from peregrine falcons.

\begin{tabular}{lccccl}
\hline Bird & $\begin{array}{c}\text { Escherichia } \\
\text { coli isolate }\end{array}$ & $\begin{array}{c}\text { Identification, log (score) } \\
\text { value in MALDI TOF }\end{array}$ & $\begin{array}{c}\text { Phylogenetic Phenotypic Resistance Virulence } \\
\text { group }\end{array}$ & $\begin{array}{l}\text { Phesistance } \\
\text { genes }\end{array}$ \\
\hline genes
\end{tabular}

$\mathrm{CIP}=$ Ciprofloxacin, $\mathrm{TE}=$ Tetracycline, $\mathrm{I}=$ Intermediate, $\mathrm{R}=$ Resistant, $\mathrm{nd}=$ Not detected

Table-4: Characterization of Enterococcus spp. strains isolated from peregrine falcons.

\begin{tabular}{|c|c|c|c|c|c|c|}
\hline $\begin{array}{l}\text { Bird sex and } \\
\text { nesting site }\end{array}$ & $\begin{array}{l}\text { Enterococcus } \\
\text { species }\end{array}$ & DNA code & $\begin{array}{l}\text { Identification log(score) } \\
\text { value in MALDI TOF }\end{array}$ & $\begin{array}{l}\text { Phenotypic } \\
\text { resistance }\end{array}$ & $\begin{array}{l}\text { Resistance } \\
\text { genes }\end{array}$ & $\begin{array}{l}\text { Virulence } \\
\text { genes }\end{array}$ \\
\hline \multirow[t]{4}{*}{ Male, Lublin } & Enterococcus & L2a & 2.315 & E15-I; MY15-R & nd & nd \\
\hline & hirae & $\mathrm{L} 2 \mathrm{~b}$ & 1.768 & E15-I; MY15-R & nd & nd \\
\hline & $\begin{array}{l}\text { Enterococcus } \\
\text { faecalis }\end{array}$ & P2 & 2.274 & $\begin{array}{l}\text { CIP5-R } \\
\text { TE30-I }\end{array}$ & $\begin{array}{l}\text { tet-(L), ant } \\
\left(4^{\prime}\right)-I a\end{array}$ & $\begin{array}{l}\text { asa1, gelE; } \\
\text { efaAfs }\end{array}$ \\
\hline & & & & $\begin{array}{c}\text { TGC15-R } \\
\text { S300-R } \\
\text { MY15-R E15-I }\end{array}$ & & \\
\hline \multirow{5}{*}{$\begin{array}{l}\text { Female } 1 \\
\text { Puławy }\end{array}$} & Enterococcus & P3a & 2.330 & CIP5-R & ant(4')-Ia; & gelE; efaAfs \\
\hline & faecalis & & & $\begin{array}{c}\text { MY15-R } \\
\text { TE30-I } \\
\text { E15-I }\end{array}$ & $\begin{array}{l}\operatorname{Tn} 916 / \\
\operatorname{Tn} 1545\end{array}$ & \\
\hline & & P3b & 2.274 & CIP5-R; & ant(4')-Ia; & gelE; efaAfs \\
\hline & & & & MY15-R & Tn916/Tn1545 & \\
\hline & & & & TE30-I & & \\
\hline
\end{tabular}

TGC15=Tigecycline, E15=Erythromycin, S300=Streptomycin, MY15=Lincomycin, CIP5=Ciprofloxacin, TE30=Tetracycline $\mathrm{nd}=$ Not detected

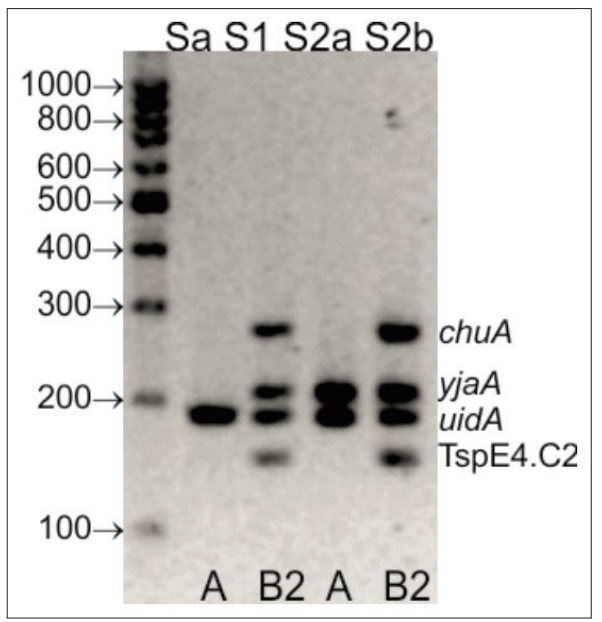

Figure-2: Polymerase chain reaction results for Escherichia coli isolates from peregrine falcons (Falco peregrinus).

Strains identified as E. faecalis showed intermediate susceptibility to tetracycline and resistance to ciprofloxacin. No isolates were resistant to vancomycin, chloramphenicol, or any of the other chemotherapeutics (Table-4). Antibiotic resistance was linked to the $\operatorname{tet}(\mathrm{L})$ gene in one strain, to $\operatorname{ant}\left(4^{\prime}\right)-\mathrm{Ia}$ and $\operatorname{Tn} 916 /$ Tn1545 in two strains, and to efaAfs in the three strains of $E$. faecalis. No drug resistance genes were shown in E. hirae strains (Table-4). A detailed analysis of the presence of resistance genes is presented in Figure-3.

The PCR analysis of virulence factors in Enterococcus spp. confirmed the simultaneous occurrence of the gelatinase gene ( $g e l E)$ and cell wall adhesin gene (efaAfs) in the three E. faecalis strains (P2, P3a, and P3b) isolated from chicks nesting in Lublin and Puławy, as well as the aggregation protein gene (asal), which was present only in E. faecalis strain P2 (Figure-4). The presence of virulence factors was not confirmed in the E. hirae strains.

Staphylococcus species were isolated only from nestlings in Puławy, based on morphological analysis confirmed by MALDI TOF MS. In total, three strains belonging to the species Staphylococcus schleiferi and one strain of $S$. aureus obtained from the male were isolated. Log score values in MALDI TOF for Staphylococcus spp. strains were $>2.0$ in the case of three strains and $>1.95$ for one strain, which indicates correct identification to species level (Table-4).

The strains did not show resistance to the chemotherapeutics used. Intermediate susceptibility to clindamycin was observed in only one $S$. schleiferi strain isolated from female 1 . Both strains isolated from the male showed intermediate susceptibility to erythromycin (Table-5). The analysis of resistance genes also did not confirm the presence of any of them.

The results of multiplex PCR showed the presence of SEE genes (170 bp) responsible for the production of enterotoxin $\mathrm{E}$ in two strains of $S$. schleiferi subsp. schleiferi (S1E and 2E2), isolated from females 1 and 2, respectively, and in the strain of $S$. aureus subsp. aureus (3E3b) from the male. In addition, the presence of the SEC (257 bp) gene responsible for the production of enterotoxin C was confirmed in the $S$. schleiferi strain isolated from the male (Figure-5). 


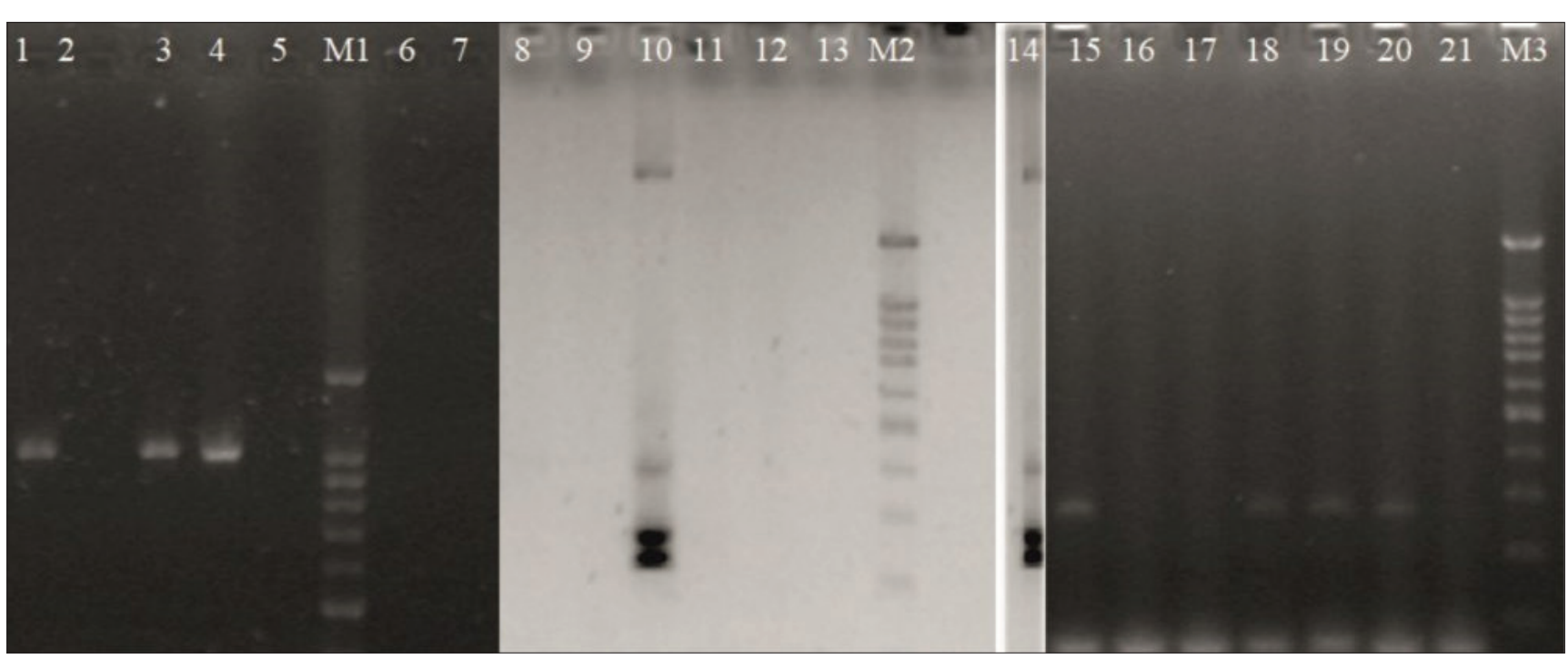

Figure-3: Resistance genes in Enterococcus spp. isolated from falcons. Lines: M1, M2, M3 - Marker Nova 100 bp DNA ladder; 1 - positive control Enterococcus faecalis UTI No. 1 for Tn916/Tn1545 - 1028 bp; 2 - E. faecalis P2 (Tn916/ Tn1545-); 3 - E. faecalis P3a (Tn916/Tn1545+); 4 - E. faecalis P3b (Tn916/Tn1545+); 5 - negative control for Tn916/ Tn1545 - 1028 bp; 6 - Enterococcus hirae L2a (Tn916/Tn1545-); 7 - E. hirae L2b (Tn916/Tn1545-); 8 - E. hirae L2a (tetL-); 9 - E. hirae L2b (tetL-); 10 - E. faecalis P2 (tetL+); 11 - E. faecalis P3a (tetL-); 12 - E. faecalis P3b (tetL-); $13-$ negative control tetL; 14 - positive control E. hirae WB No. 4 for tetL-229 bp; 15 - positive control E. faecalis WT No. 27 for ant(4')-Ia -294 bp; 16 - E. hirae L2a (ant(4')-Ia-); 17- E. hirae L2b (ant(4')-Ia-); 18 - E. faecalis P2 (ant(4')-Ia+); 19 - E. faecalis P3a (ant(4')-Ia+); 20- E. faecalis P3b (ant(4')-Ia+); 21- negative control.

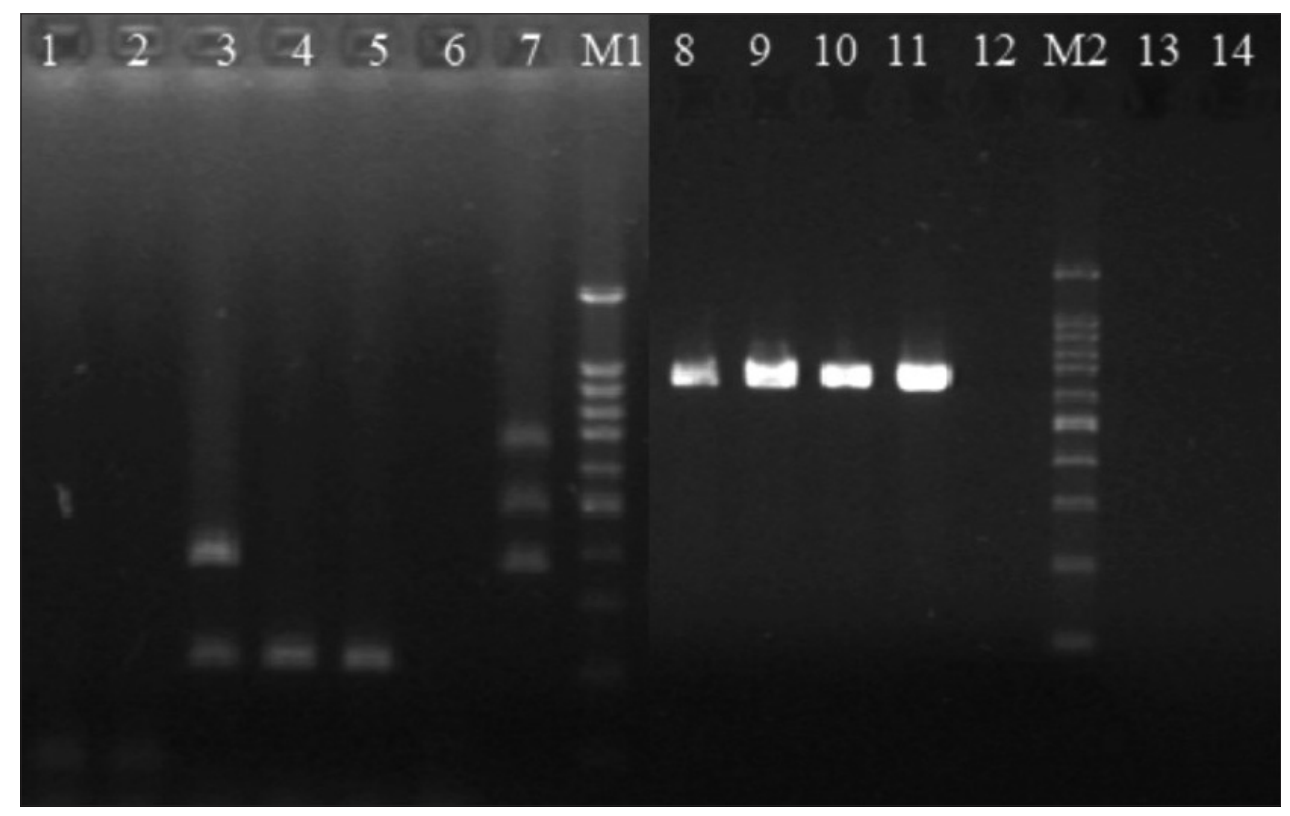

Figure-4: Virulence factors in Enterococcus spp. isolates from peregrine falcons. Lines: M1, M2 - Marker Nova 100 bp DNA ladder; 1 - Enterococcus hirae L2a; 2 - E. hirae L2b; 3 - Enterococcus faecalis P2 (asa1 +, gelE+); 4 - E. faecalis P3a $(g e l E+) ; 5-E$. faecalis P3b (gelE+); 6 - negative control; 7 - positive control E. faecalis WT3 for genes: cylA - 688 bp; esp - 510bp; asa1 - 375 bp; 8 - E. faecalis P2 (efaAfs+); 9 - E. faecalis P3a (efaAfs+); 10 - E. faecalis P3b (efaAfs+); 11 - positive control E. faecalis ATCC29212 (efaAfs-); 12 - negative control; 14M -13 - E. hirae L2a (efaAfs-); 14 - E. hirae L2b (efaAfs-).

\section{Parasitic identification}

Only one species of coccidia was found in the material; it was identified as Caryospora falconis. The intensity of infection was 1800 OPG. Oocysts $(n=20)$ were spherical to subspherical, ranging in size from $31.5 \mu \mathrm{m}$ to $36.5 \mu \mathrm{m}$ (average $32.5 \times 34.0 \mu \mathrm{m}$ ), with smooth bilayered walls without micropyles. Single sporocysts containing eight sporozoites were spherical (average diameter $21 \mu \mathrm{m}$ ), with no Stieda body and with a sporocyst residuum present as a diffuse spherical mass (Figure-6).

\section{Heavy metals analysis}

Toxicological analysis of feather and fecal samples obtained from the falcons revealed high concentrations of $\mathrm{Cd}, \mathrm{Cu}, \mathrm{Pb}, \mathrm{Zn}$, and As in all samples. The highest concentrations in both fecal and feather samples were observed for $\mathrm{Cu}(11.33 \mu \mathrm{g} / \mathrm{g}$ and $15.42 \pm 0.83 / \mathrm{g}$ of sample, respectively) and $\mathrm{Zn}$ (42.05 
and $22.04 \mu \mathrm{g} / \mathrm{g}$ of sample). The average values of the elements exceeded the concentrations detected and

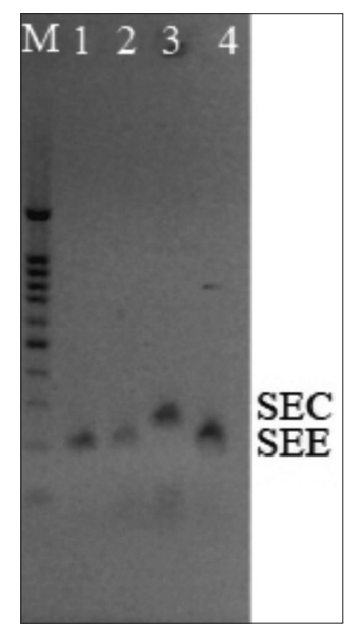

Figure-5: Results of the detection of enterotoxicity genes in Staphylococcus spp. isolates from peregrine falcons (Falco peregrinus). M - mol. weight standard 1001000 bp and 1500 bp (Nova 100 bp DNA Ladder, 250); Line 1 - Staphylococcus schleiferi S1E, Line 2 - S. schleiferi 2E2; Line 3 - S. schleiferi 3E3a; Line 4 - Staphylococcus aureus $3 \mathrm{E} 3 \mathrm{~b}$.

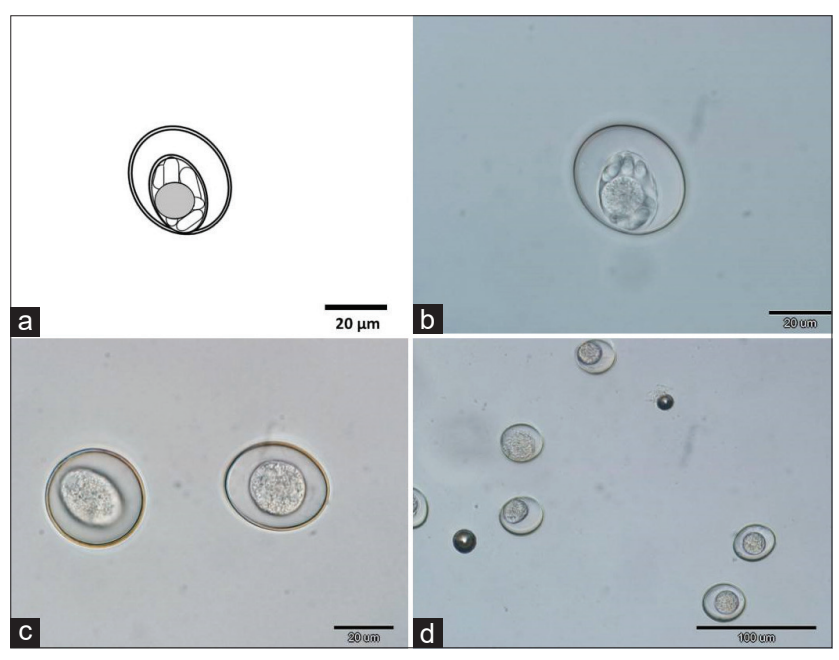

Figure-6: Cyclospora falconis from young peregrine falcons. Line drawing of mature oocyst, showing details: (a) Subspherical sporocyst with banana-shaped sporozoites and spherical residuum. (b) The same living oocyst as in the line drawing in differential interference contrast light microscopy, (c and d) unsporulated oocysts isolated from fresh fecal samples. recognized as toxic in other studies even ten-fold. Detailed data are presented in Table-6 [32-35].

\section{Discussion}

Free-living birds nesting in urban ecosystems may be particularly exposed to contact with common zoonotic pathogens posing a threat to animals and humans. In addition, they are particularly vulnerable to poisoning with heavy metals arising during manufacturing processes. Numerous studies $[32,33]$ confirm the large role of pollutants associated with highly urbanized and industrialized regions in the accumulation of heavy metals and other toxic compounds in birds. The presence of bacterial agents in free-living birds as a potential reservoir of pathogens has also recently become a subject of research, due in part to the potential threat posed to domestic animals and humans [19].

The present study found pathogenic E. coli, Enterococcus spp. and Staphylococcus spp. bacteria and C. falconis parasites in peregrine falcons nesting in urban environments. It should be emphasized that single virulence genes were found among the bacterial isolates: (irp-2, pic, astA, and irp-2) in E. coli belonging to phylogenetic groups A and B2; enterotoxicity genes (SEC and SEE) in Staphylococcus spp.; and three genes coding for virulence factors (asal, gelE, and efaAfs) in Enterococcus faecalis. Similar results for the occurrence of bacterial strains in wild birds were observed in a study by Chung et al. [2], in which the most frequently identified bacteria were $E$. coli and Campylobacter jejuni. In another study [36], E. coli isolates from wild birds were also mainly assigned to phylogenetic Groups A and B2. According to these authors, the prevalence of a given species may depend on the geographic zone, the species and order of bird, the migratory status of the bird species, its habitat type, and the species, family, and phylum of bacteria associated with the bird.

A positive finding of our research was the low resistance of the bacterial isolates to the antibiotics tested. In the case of E. coli strains, resistance to tetracycline was found in only one isolate, which was also confirmed by the presence of the tetracycline resistance gene tet(A) in two of the four isolates. The presence of tetracycline resistance genes in E. coli strains

Table-5: Characterization of Staphylococcus spp. strains isolated from peregrine chicks.

\begin{tabular}{llcccc}
\hline $\begin{array}{l}\text { Bird sex and } \\
\text { nesting site }\end{array}$ & $\begin{array}{l}\text { Staphylococcus } \\
\text { species }\end{array}$ & DNA code & $\begin{array}{c}\text { Identification log(score) } \\
\text { value in MALDI TOF }\end{array}$ & $\begin{array}{c}\text { Phenotypic } \\
\text { resistance }\end{array}$ & $\begin{array}{l}\text { Resistance } \\
\text { genes }\end{array}$ \\
\hline Female 1 Puławy & $\begin{array}{l}\text { Staphylococcus } \\
\text { schleiferi }\end{array}$ & S1E & 2.029 & DA2- I & nd \\
Female 2 Puławy & $\begin{array}{l}\text { Staphylococcus } \\
\text { schleiferi }\end{array}$ & $2 \mathrm{E} 2$ & 2.037 & nd & nd \\
Female 3 Puławy & $\begin{array}{l}\text { nd } \\
\text { Staphylococcus } \\
\text { schleiferi }\end{array}$ & 3E3a & - & - & - \\
Staphylococcus & 3E3b & 1.959 & E15-I & nd \\
& aureus & 2.042 & E15-I & nd \\
\hline
\end{tabular}

E15-I=Erythromycin intermediate resistance, DA2-I=Clindamycin 2 intermediate resistance, nd= Not detected 
Table-6: Average concentrations of $\mathrm{Cd}, \mathrm{Cu}, \mathrm{Pb}, \mathrm{As}$, and $\mathrm{Zn}$ in samples obtained from peregrine chicks.

\begin{tabular}{|c|c|c|c|c|c|}
\hline \multirow[t]{2}{*}{ Element } & \multicolumn{2}{|c|}{ Concentration $\mu \mathrm{g} / \mathrm{g}$} & \multirow[t]{2}{*}{$P \leq 0.05$} & \multirow{2}{*}{$\begin{array}{l}\text { Range in studies by } \\
\text { other authors } \mu \mathrm{g} / \mathrm{g}\end{array}$} & \multirow[t]{2}{*}{ References } \\
\hline & Feces & Feathers & & & \\
\hline $\mathrm{Cd}$ & $0.319 \pm 0.036$ & $<0.001$ & 0.0001 & $\begin{array}{l}0.63-0.76 \\
>0.08\end{array}$ & $\begin{array}{l}\text { Mansouri and Majnoni, [32]; } \\
\text { Ek et al. [34] }\end{array}$ \\
\hline $\mathrm{Pb}$ & $2.46 \pm 0.1$ & $1.08 \pm 0.05$ & 0.0002 & $\begin{array}{l}1.3-2.43 \\
>0.09\end{array}$ & $\begin{array}{l}\text { Gruz et al. } \\
\text { Ek et al. }[34]\end{array}$ \\
\hline $\mathrm{Cu}$ & $15.42 \pm 0.83$ & $11.33 \pm 0.4$ & 0.0002 & $\begin{array}{c}5.28-8.33 \\
>8\end{array}$ & Ek et al. [34] \\
\hline $\mathrm{Zn}$ & $42.05 \pm 6.42$ & $22.04 \pm 1.57$ & 0.00015 & $\begin{array}{c}24.12-25.77 \\
>45\end{array}$ & Ek et al. [34] \\
\hline As & $0.04 \pm 0.003$ & $<0.005$ & 0.07 & $0.161>200$ & Burger, [35] \\
\hline
\end{tabular}

$\mathrm{Cd}=$ Cadmium, $\mathrm{Pb}=$ Lead, As=Arsenic, $\mathrm{Zn}=$ Zinc, $\mathrm{Cu}=$ Copper

isolated from wild birds has also been demonstrated by other authors [36].

Bacteria of the genus Staphylococcus did not show resistance to the antibiotics, which was linked to the lack of resistance genes confirmed by PCR. In the case of these two nests, the peregrine falcons were shown not to be exposed to drug-resistant Staphylococcus bacteria posing a potential threat to birds and the environment, which is a highly favorable finding. The results differ from those reported by Chung et al. [2], who detected various antibiotic resistance genes in Staphylococcus spp. isolated from wild birds. In our study, however, samples were collected from only two nests.

By far, the most numerous source of resistance was Enterococcus spp. strains, among which resistance was demonstrated against six of the 17 antibiotics (tetracycline, tigecycline, erythromycin, streptomycin, lincomycin, and ciprofloxacin). This was linked to the presence of as many as five resistance genes among the strains isolated from chicks.

High resistance to tetracycline (about $71 \%$ ) in bacteria isolated from other species of wild birds, including as migratory and non-migratory birds, especially among strains of Staphylococcus spp., E. coli, and Enterococcus spp., was observed in an extensive analysis presented by Chung et al. [2]. Other studies [1,37], conducted in wild geese, cormorants, and birds of prey, have also confirmed resistance to beta-lactam antibiotics in $E$. coli strains, which was confirmed by the presence of resistance genes, including tet(A)/tet(B), aadA, sul1/sul2/sul3, and qnr. In our study, the presence of a resistance gene in E. coli strains was demonstrated only for tetracycline, which may be due in part to the very small number of strains obtained from the six chicks $(n=4)$. However, the resistance to tetracycline shown in our research is consistent with the results of the works cited above and confirms the occurrence of resistant strains as well as tetracycline resistance genes among bacteria isolated from wild birds.

The largest group of resistant microorganisms isolated from samples obtained from peregrine falcon chicks was strains of Enterococcus spp. The resistance to tetracycline, erythromycin, lincomycin, ciprofloxacin, tigecycline, and streptomycin demonstrated in the isolates represents a serious threat not only to domestic and livestock animals but also to people as well. Our previous work [15] demonstrated a high percentage of strains resistant to lincomycin $(100 \%)$, tetracycline $(48 \%)$, and erythromycin (44\%) among isolates from other species of free-living birds. These results also confirm reports by Marrow et al. [38], who showed a very high prevalence percentage $(95 \%)$ of $E$. faecalis strains in wild birds and a high percentage of resistance to second-generation cephalosporins and erythromycin. Similar results are reported in a study by Radhouani et al. [36], in which $87.1 \%$ of Enterococcus spp. isolates were resistant to tetracycline and $80.6 \%$ to erythromycin. In addition, about $30 \%$ of the strains were resistant to ciprofloxacin.

The presence of resistance genes in the E. faecalis strains isolated from peregrine falcons, which determine resistance to tetracycline, lincomycin, erythromycin, ciprofloxacin, and tigecycline, also confirms the results of previous research $[39,40]$, in which samples from birds of prey as well as from passerines and waterfowl were tested. In that study, most of the resistance genes were found in the species $E$. faecalis, which is also consistent with results reported by Radhouani et al. [36]. The presence of such a large population of genes determining resistance to the above-mentioned antibiotics among Enterococcus strains suggests that free-living predators are potential indicators of these genes.

Parasitological analysis of the material obtained from the peregrine falcon chicks confirmed the presence of the coccidian parasite C. falconis in numbers indicating moderate intensity of infection (1800 OPG). Caryospora is the third largest genus in the family Eimeriidae, and its members infect primarily predatory birds and reptiles [41]. At least 25 species of Caryospora have been identified from wild birds [42]. To date, 15 species have been identified in raptor birds worldwide, while nine species have been recorded only in falconids from Asia, Europe, and North America. Members of the genus Caryospora are the most important cause of gastrointestinal disorders in falcons $[43,44]$, especially in young birds from breeding facilities. The host specificity of $C$. falconis is 
difficult to determine; it is unclear whether it is a species-specific parasite. Thus, far $C$. falconis has been found in F. peregrinus, Falco subbuteo, and Falco tinnunculus in the European population.

A high level of immunity plays an important role in resistance to bacterial and parasitic infections in wild birds. Many factors, including heavy metals, primarily $\mathrm{As}, \mathrm{Pb}$ and $\mathrm{Cd}, \mathrm{Zn}$, and $\mathrm{Cu}$, can significantly limit natural immune mechanisms in birds, increasing their susceptibility to infection. Data presented by other authors $[32,32,45]$ indicate that the concentration of heavy metals is dependent on the nesting and migration sites of birds, as well as their individual and species characteristics, including species resistance, age, sex, and health status. In many cases, close proximity of birds to highly urbanized areas is an important factor in increasing the accumulation of these elements in the internal organs (liver, kidneys, and lungs) and skin appendages (feathers and talons), thereby weakening the birds [46].

Our study found high concentrations of $\mathrm{Pb}, \mathrm{Cu}$, and $\mathrm{Zn}$ in the feces $(2.26,15.42$, and $42.05 \mu \mathrm{g} / \mathrm{g}$, respectively) and feathers $(1.08,11.33$, and $22.04 \mu \mathrm{g} / \mathrm{g}$ ) of peregrine chicks. These concentrations are higher than those reported in other studies [32,33], which were considered toxic for predatory birds, including peregrines. In the case of $\mathrm{Cd}$ and $\mathrm{As}$, the concentrations were lower than those found in other studies $[32,34,45]$.

Various ranges of heavy metal concentrations have been found in the feathers of free-living birds; in penguins, for example, $\mathrm{Cd}$ levels ranged from $<0.01 \mu \mathrm{g} / \mathrm{g}$ in the young to $1.9 \mu \mathrm{g} / \mathrm{g}$ in adult birds living in the vicinity of Iceland and King George Island [47]. Licata et al. [45] showed that a high percentage of deaths in buzzards are due to chronic heavy metal poisoning, for example, with $\mathrm{Pb}$ or $\mathrm{Cd}$. Based on the accumulation properties of the heavy metals, the authors established toxic values from $0.10 \mu \mathrm{g} / \mathrm{g}$ for $\mathrm{Cd}$ and from $1.60 \mu \mathrm{g} / \mathrm{g}$ for $\mathrm{Pb}$. The concentrations of $0.319 \mu \mathrm{g} / \mathrm{g}$ for $\mathrm{Cd}$ and $2.46 \mu \mathrm{g} / \mathrm{g}$ for $\mathrm{Pb}$ in our study clearly represent a level of toxicity that could affect the health status and welfare of these birds. The high $\mathrm{Zn}$ level, particularly in the feathers of the chicks $(42.05 \mu \mathrm{g} / \mathrm{g})$, seems to be a cause for concern, as it significantly exceeded the value of $24.1 \mu \mathrm{g} / \mathrm{g}$ obtained by other authors $[32,47]$. Moreover, due to the cumulative properties of $\mathrm{Zn}$, this element should be taken into account in the assessment of the risk for birds, especially chicks living in urban areas.

\section{Conclusion}

To sum up, the results of the study indicate that free-living birds are biological indicators of environmental pollution, antimicrobial resistance, and resistance genes. In addition, high concentrations of heavy metals and other toxic elements may have affected their health and welfare during the rearing period.

\section{Authors' Contributions}

EP: Conceptualization; data curation, material collection and initial isolation of bacteria. MD: Methodology and characterization of E. coli bacteria, writing of $E$. coli methodology and figure preparation. DS: Methodology and characterization of Enterococcus spp., writing of Enterococcus spp. methodology. AM: Methodology and characterization of Staphylococcus spp., JLVP: Participation in toxicology analysis. AC: Participation in toxicology analysis, with resources and writing of this part of the manuscript. KS: Parasitology testing with writing and visualization of this part of the manuscript. RU: Project administration, resources, writing - review and editing, software; statistical analysis, preparation of tables and figures. All authors read and approved the final manuscript.

\section{Acknowledgments}

We would like to thank all persons who participated in this study. The authors did not receive any funds for this study.

\section{Competing Interests}

The authors declare that they have no competing interests.

\section{Publisher's Note}

Veterinary World remains neutral with regard to jurisdictional claims in published map and institutional affiliation.

\section{References}

1. Bonnedahl, J. and Järhult, J.D. (2014) Antibiotic resistance in wild birds. Upsala J. Med. Sci., 119(2): 113-116.

2. Chung, D.M, Ferree, E., Simon, D.M. and Yeh, P.J. (2018) Patterns of bird-Bacteria associations. Ecohealth., 15(11): 627-641.

3. Greig, J., Rajić, A., Young, I., Mascarenhas, M., Waddell, L. and LeJeune, J. (2014) A scoping review of the role of wildlife in the transmission of bacterial pathogens and antimicrobial resistance to the food chain. Zoon. Public Health, 62(4): 269-284.

4. Atterby, C., Ramey, A.M., Hall, G.G., Järhult, J., Börjesson, S. and Bonnedahl, J. (2016) Increased prevalence of antibiotic-resistant $E$. coli in gulls sampled in South Central Alaska is associated with urban environments. Infect. Ecol. Epidemiol., 6: 32334.

5. White, C.M., Cade, T.J. and Enderson, J.H. (2013) Peregrine Falcons of the World. Lynx Edicions, Barcelona.

6. White, C.M., Sonsthagen, S.A., Sage, G.K., Anderson, C. and Talbot, S.L. (2013) Genetic relationships among some subspecies of the peregrine falcon (Falco peregrinus L.), inferred from mitochondrial DNA control-region sequences. Auk, 130(1): 78-87.

7. Palmgren, H., Broman, T., Waldenström, J., Lindberg, P., Aspán, A. and Olsen, B. (2004) Salmonella Amager, Campylobacter jejuni, and urease-positive thermophilic campylobacter found in free-flying peregrine falcons (Falco peregrinus) in Sweden. J. Wild. Dis., 40(3): 583-587.

8. De Luca, C., Niero, G., Cattarossi, D., Bendin, M., De Luca, C. and Piccirillo A. (2018) Pet and captive birds as potential reservoirs of zoonotic Bacteria. J. Exot. Pet Med., 27(1): 17-20.

9. Ziegler, L., Möller, P.F., Enderlein, D., Herbst, W., 
Schmidt, L. and Lierz, M. (2019) Mycoplasma hafezii sp. nov., isolated from the trachea of a peregrine falcon (Falco peregrinus). Int. J. Syst. Evol. Microbiol., 69(3): 773-777.

10. Kabata-Pendias, A. (2000) Biogeochemia kadmu. W: Kadm w środowisku. Problemy ekologiczne i metodologiczne. Kabata-Pendias A., Szteke B (red.) PAN, komitet naukowy przy prezydium PAN, Człowiek i środowisko. Zesz. Nauk., 26: 17-24.

11. Czeczot, H. and Skrzycki, M. (2010) Kadm-pierwiastek całkowicie zbędny dla organizmu/Cadmium-element completely unnecessary for the organism. Postępy Hig. Med. Dosw., 64: 38-49.

12. Valverde Piedra, J.L., Zienkiewicz, A., Khudhur, H.B., Szymańczyk, S.E. and Rumińska, E. (2018) Influence of the administration of propolis and bee pollen preparation on the concentration of mercury in the muscles, kidneys and liver of white storks. Med. Weter., 74(3): 171-174.

13. Samour, J. (2008) Toxicology. In: Samour, J., editor. Avian Medicine. $2^{\text {nd }}$ ed. Mosby Elsevier, Edinburgh, p269-281.

14. Dec, M., Urban-Chmiel, R., Gnat, S., Puchalski, A. and Wernicki, A. (2014) Identification of Lactobacillus strains of goose origin using MALDI-TOF mass spectrometry and $16 \mathrm{~S}-23 \mathrm{~S}$ rDNA intergenic spacer PCR analysis. Res. Microbiol., 165(3): 190-201.

15. Stępień-Pyśniak, D., Hauschild, T., Różański, P. and Marek, A. (2017) MALDI-TOF mass spectrometry as a useful tool for identification of Enterococcus spp. from wild birds and differentiation of closely related species. $J$. Microbiol. Biotechnol., 27(6): 1128-1137.

16. Feng, Y., Mannion, A., Madden, C.M., Swennes, A.G., Townes, C., Byrd, C., Marini, R.P. and Fox, J.G. (2017) Cytotoxic Escherichia coli strains encoding colibactin and cytotoxic necrotizing factor (CNF) colonize laboratory macaques. Gut Pathog., 9: 71.

17. Clinical and Laboratory Standards Institute. (2018) M60: Performance Standards for Antifungal Susceptibility Testing of 244 Yeast. $1^{\text {st }}$ ed. Clinical and Laboratory Standards Institute, Wayne, PA.

18. Kozak, G.K., Boerlin, P., Janecko, N., Reid-Smith, R.J. and Jardine, C. (2009) Antimicrobial resistance in Escherichia coli isolates from swine and wild small mammals in the proximity of swine farms and in natural environments in Ontario, Canada. Appl. Environ. Microbiol., 75(3): 559-66.

19. Turchi, B., Dec, M., Bertelloni, F., Winiarczyk, S., Gnat, S., Bresciani, F., Viviani, F., Cerri, D. and Fratini, F. (2019) Antibiotic susceptibility and virulence factors in Escherichia coli from sympatric wildlife of the Apuan Alps regional park (Tuscany, Italy). Microb. Drug Resist., 25(5): 772-780.

20. Paton, A.W. and Paton, J.C. (2002) Direct detection and characterization of Shiga toxigenic Escherichia coli by multiplex PCR for stx1, stx2, eae, ehxA, and saa. J. Clin. Microbiol., 40(1): 271-274.

21. van der Westhuizen, W.A. and Bragg, R.R. (2012) Multiplex polymerase chain reaction for screening avian pathogenic Escherichia coli for virulence genes. Avian Pathol., 41(1): 33-40.

22. Ewers, C., Janssen, T., Kiessling, S., Philipp, H.C. and Wieler, LH. (2005) Rapid detection of virulence-associated genes in avian pathogenic Escherichia coli by multiplex polymerase chain reaction. Avian Dis., 49(2): 269-273.

23. Stępień-Pyśniak, D., Hauschild, T., Nowaczek, A., Marek, A. and Dec, M. (2018) Wild birds as a potential source of known and novel multilocus sequence types of antibiotic-resistant Enterococcus faecalis. J. Wildl. Dis., 54(2): 219-228.

24. Naser, S.M., Thompson, F.L., Hoste, B., Gevers, D. Dawyndt, P., Vancanneyt M. and Swings, J. (2005) Application of multilocus sequence analysis (MLSA) for rapid identification of Enterococcus species based on rpoA and pheS genes. Microbiology, 151(7): 2141-2150.

25. Dec, M., Stępień-Pyśniak, D., Gnat, S., Fratini, F.,
Urban-Chmiel, R., Cerri, D., Winiarczyk, S. and Turchi, B. (2020) Antibiotic susceptibility and virulence genes in Enterococcus isolates from wild mammals living in Tuscany, Italy. Microb. Drug Resist., 26(5): 505-519.

26. Marek, A., Stępień-Pyśniak, D., Pyzik, E., Adaszek, Ł., Wilczyński, J. and Winiarczyk, S. (2016) Occurrence and characterization of Staphylococcus bacteria isolated from poultry in Western Poland. Berl Munch Tierarztl Wochenschr, 129(3-4): 147-152.

27. Nijage, P.M., Dolci, S., Janas, C., Lacroix, C. and Meile, L. (2013) Phenotypic and genotypic antibiotic resistance patterns of Staphylococcus aureus from raw and spontaneously fermented camel milk. Br. J. Appl. Sci.Technol., 3(3): 87-98.

28. Gardette, S. and Tomasz, A. (2014) Mechanisms of vancomycin resistance in Staphylococcus aureus. J. Clin. Invest., 124(7): 2836.

29. Pyzik, E., Marek, A., Stępień-Pyśniak, D., UrbanChmiel, R., Jarosz, Ł. and Jagiełło-Podębska, I. (2019) Detection of antibiotic resistance and classical enterotoxin genes in coagulase-negative staphylococci isolated from poultry in Poland. J. Vet. Res., 63: 183-190.

30. Pellerdy, L.P. (1974) Coccidia and Coccidiosis. Akademia Kiado, Budapest, p192.

31. Lodenius, M. and Solonen, T. (2013) The use of feathers of birds of prey as indicators of metal pollution. Ecotoxicology, 22(9): 1319-1334.

32. Mansouri, B. and Majoni, F. (2014) Comparison of the metal concentrations in organs of two bird species from West Iran. Bull. Environ. Contam. Toxicol., 92(4): 433-439.

33. Grúz, A., Mackle, O., Bartha, A., Szabó, R., Déri, J., Budai, P. and Lehe, J. (2019) Biomonitoring of toxic metals in feathers of predatory birds from eastern regions of Hungary. Environ. Sci. Pollut. Res., 26(2): 26324-26331.

34. Ek, K.H., Morrison, G.M., Lindberg, P. and Rauch, S. (2004) Comparative tissue distribution of metals in birds in Sweden using ICP-MS and laser ablation ICP-MS. Arch. Environ. Contam. Toxicol., 47(2): 259-269.

35. Burger, J. (2008) Assessment of metals in down feathers of female common eiders and their eggs from the Aleutians: Arsenic, cadmium, chromium, lead, manganese, mercury, and selenium. Environ. Monit. Assess., 143(1-3): 247-256.

36. Radhouani, H., Poeta, P., Goncalves, A., Pacheco, R., Sargo, R. and Igrejas, G. (2012) Wild birds as biological indicators of environmental pollution: Antimicrobial resistance patterns of Escherichia coli and enterococci isolated from common buzzards (Buteo buteo). J. Med. Microbiol., 61(6): 837-843.

37. Costa, D., Poeta, P., Saenz, Y., Vinue, L., Rojo-Bezares, B., Jouini, A., Zarazaga, M., Rodrigues, J. and Torreset, C. (2006) Detection of Escherichia coli harbouring extended-spectrum beta-lactamases of the CTX-M, TEM and SHV classes in faecal samples of wild animals in Portugal. J. Antimicrob. Chemother., 58(6): 1311-1312.

38. Marrow, J., Whittington, J.K., Mitchell, M., Hoyer, L.L. and Maddox, C. (2009) Prevalence and antibiotic-resistance characteristics of Enterococcus spp. Isolated from free-living and captive raptors in central Illinois. J. Wildl. Dis., 45(2): 302-313.

39. Stępień-Pyśniak, D., Hauschild, T., Dec, M., Marek, A. and Urban-Chmiel, R. (2019a) Clonal structure and antibiotic resistance of Enterococcus spp. from wild birds in Poland. Microbial. Drug Res., 25(8): 1227-1237.

40. Stępień-Pyśniak, D., Hauschild, T., Kosikwska, U., Dec, M. and Urban-Chmiel, R. (2019b) Biofilm formation capacity and presence of virulence factors among commensal Enterococcus spp. from wild birds. Sci. Rep., 9(1): 11204.

41. Upton, S.J., Current, W.L. and Barnard, S.M. (1986) A review of the genus Caryospora léger, 1904 (Apicomplexa: Eimeriidae). Syst. Parasitol., 8(3): 3-21.

42. Santana-Sánchez, G., Flores-Valle, I.T., GonzálezGómez, M., Vega-Sánchez, V., Salgado-Miranda, C. and Soriano-Vargasa, E. (2015) Caryospora neofalconis 
and other enteroparasites in raptors from Mexico. Int. J. Parasitol. Parasites Wildl., 4(3): 351-355.

43. Upton, S.J., Campbell, T.W., Weigel, M. and McKown, R.D. (1990) The Eimeriidae (Apicomplexa) of raptors: Review of the literature and description of new species of the genera Caryospora and Eimeria. Can. J. Zool., 68(6): 1256-1265.

44. Pavlík, I., Cerník, J., Bárta, J., Kundera, J. and Pecka, Z. (1998) Occurrence of coccidia (Caryospora neofalconis and Caryospora kutzeri) in birds of prey in falcon breeding facility in Milotice in the Czech Republic.Vet. Med. Czech, 43: 301-306.

45. Licata, P., Naccari, F., Lo Turco, V., Rando, R., Di Bella, G. and Dugo, G. (2010) Levels of Cd (II), Mn (II), Pb (II),
$\mathrm{Cu}$ (II), and $\mathrm{Zn}$ (II) in common buzzard (Buteo buteo) from Sicily (Italy) by derivative stripping potentiometry. Int. J. Ecol., 2010:541948.

46. Liu, J., Liang, J., Yuan, X., Zeng, G., Yuan, Y., Wu, H., Huang, X., Liu, J., Hua, S., Li, F. and Li, X. (2015) An integrated model for assessing heavy metal exposure risk to migratory birds in wetland ecosystem: A case study in Dongting Lake Wetland, China. Chemosphere, 135: 14-19.

47. Jerez, S., Motas, M., Benzal, J., Diaz, J., Vidal, V., D'Amico, V. and Barbosa, A. (2013) Distribution of metals and trace elements in adult and juvenile penguins from the Antarctic Peninsula area. Environ. Sci. Pollut. Res., 20(5): 3300-3331.

$* * * * * * * *$ 